\title{
The carrion beetle Oxelytrum discicolle (Coleoptera: Silphidae) and the estimative of the minimum post-mortem interval in a forensic case in Brasília, Brazil
}

\author{
Luiz Antonio Lira ${ }^{1,2, *}$ (D), Karine Brenda Barros-Cordeiroํㅜ, Beatriz Figueiredo³, \\ Malthus Fonseca Galvão ${ }^{4,5}$, Marina Regina Frizzas ${ }^{1}$
}

${ }^{1}$ Universidade de Brasília, Instituto de Ciências Biológicas, Departamento de Zoologia, Brasília, DF, Brasil.

${ }^{2}$ Universidade Católica de Brasília, Campus I, Curso de Ciências Biológicas, Brasília, DF, Brasil.

${ }^{3}$ Polícia Civil do Distrito Federal, Instituto de Criminalística, SAISO Complexo da Polícia Civil, Brasília, DF, Brasil.

${ }^{4}$ Universidade de Brasília, Faculdade de Medicina, Departamento de Patologia, Brasília, DF, Brasil.

${ }_{5}^{5}$ Polícia Civil do Distrito Federal, Instituto de Medicina Legal, SAISO Complexo da Polícia Civil, Brasília, DF, Brasil.

\section{A R T I C L E I N F O}

\section{Article history:}

Received 07 September 2019

Accepted 14 October 2019

Available online 17 January 2020

Associate Editor: Adriana Marvaldi

\section{Keywords}

Entomological evidence

Forensic entomology

Insect larvae

PMI

\begin{abstract}
A B S T R A C T
The order Coleoptera is considered second highest in forensic importance in criminal cases involving violent death, because members of this order increase in richness and abundance as the decomposition process progresses. We present here the first Forensic Entomology (FE) case in Brazil where the carrion beetle, Oxelytrum discicolle (Coleoptera: Silphidae), was used to estimate the minimum post-mortem interval (m-PMI) in a forensic case. A female corpse, at an advanced stage of decomposition, was found on a deserted highway near Brasília/Brazil. The corpse was removed from the site, and insect samples were collected on and inside the corpse at the Forensic Medicine Institute of the Federal Police, following the specific FE protocols. The m-PMI was estimated considering two techniques, the pre-appearance interval (PAI) and the accumulated degree-days (ADD). The development stage of the larvae of $O$. discicolle allowed investigators to propose that this species was part of an earlier colonization, soon after death, with total length and prothorax width compatible with third instar larvae. Adult females of $O$. discicolle oviposited on the corpse at least 20 days before it was removed from the site where it was found, thus characterizing the m-PMI. This is the first case in which information on the development of the $O$. discicolle was used in a criminal investigation in Brazil.
\end{abstract}

The order Coleoptera is considered second highest in forensic importance in criminal cases involving violent death. Among the families of forensic importance, Silphidae, or carrion beetles, stand out for their necrophagous habits in its immature stage and omnivorous habits as adults. This group consists of the subfamilies Nicrophorinae and Silphinae, which recorded over 100 species in temperate regions, and 82 in Neotropical regions with (Peck and Anderson, 1985). The adults measure between 10 and $35 \mathrm{~mm}$ in length and present vivid colors on the scutellum (Fig. 1A). The larvae are campodeiform, strongly sclerotized, and have laterally prolonged flap-like tergites (Fig. 1B).

The species Oxelytrum discicolle(Brullé, 1840) is widely distributed in the Americas, from the southern United States to southern Brazil, except in the Amazon region (Peck and Anderson, 1985). Studies on beetles associated with carcasses have been conducted in Brazil

\footnotetext{
* Corresponding author:

E-mail: lirajuniorunb@gmail.com (L. A. Lira).
}

since the last century. In 1911, Luederwaldt (1911) found 62 species associated with animal decomposition, while Mise et al. (2007) recorded 112 species. In 2015, a paper compiled the records available in the literature and produced a list of Coleoptera that of forensic importance in the country, devising a total of 345 species from 16 families, with occurrence in 16 Brazilian states (Almeida et al., 2015). O. discicolle was reported in all of these articles. Although beetles are often treated as secondary in forensic investigations, carrion beetles are prominent in Forensic Entomology because larvae of $O$. discicolle feed exclusively on decaying tissues, while the adult species feed on decaying tissues and sometimes on fly larvae.

O. discicolle has a preference for moist environments such as seasonal and high altitude forests, and the species can also be found in urban environments (Carvalho et al., 2000; Lira and Vasconcelos, 2016). The adult presents omnivorous (preferably scavengers), habits and can prey on the larvae of flies and decaying animal substrate, while the immature forms are typically scavengers (Oliva and Di-Iorio, 
A

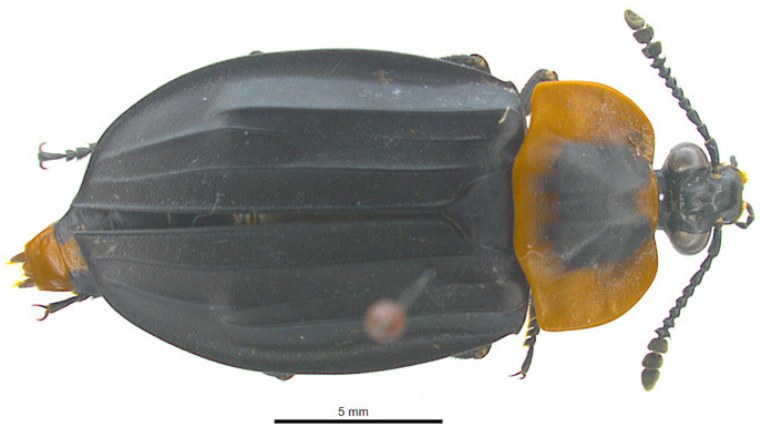

B

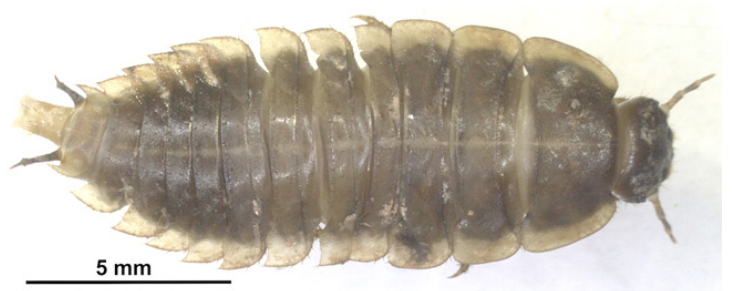

Figure 1. (A) Oxelytrum discicolle adult in dorsal view; (B) Oxelytrum discicolle third instar larvae in dorsal view.

2008). Recently, experimental ecological studies have shown that O. discicolle presents a high attraction to carcasses in advanced stages of decomposition, and they are more abundant during rainy periods in the Cerrado vegetation (Lira et al., 2019), which supported the use of this species to estimate PMI in the present case, suggesting colonization closer to the date of the victim`s death.

Here we describe a forensic entomological case in Brasília, central Brazil, in which $O$. discicolle was used for the first time in the Neotropical region to estimate the minimum post-mortem interval ( $\mathrm{m}$-PMI) of a corpse that was in the colliquative decomposition stage. In this forensic case, this carrion beetle was verily characterized as species of forensic interest.

\section{Case report}

On March 31 st, at the end of the region's rainy season, the corpse of a woman was found near a deserted highway in a patch of vegetation of Cerrado Sensu Stricto, near the city of Brasília. After the investigators' analysis at the crime scene, the corpse was transported to the Instituto Médico Legal/IML (the Brazilian Forensic Medicine Institute) in Brasília/DF, where the routine procedures for identification were performed. The corpse was in an advanced stage of decomposition. The ventral parts, which were in contact with the soil, were in the full colliquative decomposition stage, whilst the dorsal surface of the body, had multiple mummified areas. Weather data was collected in loco and at the nearest station to the crime scene, approximately $5 \mathrm{~km}$ away.

The coroner's analysis found cranial and chest in the body, which does not exclude the possibility of other lesions in the tissue destroyed by putrefaction. The clothes were partially burned and the body did not present any vital reaction to thermal action, which suggests that there was an attempt to burn the body with the intention of destroying evidence at the crime scene. There was no record of fire and no other decomposition accelerator in this case, absence of smoke scent. After comparisons with photographs and dental records, the body was identified as a 57-year old female, reported missing by the family. On April $1^{\text {st }}$, during the necropsy, eight larvae of beetle were collected from inside the corpse (Fig. 2). The collected insects were transferred to

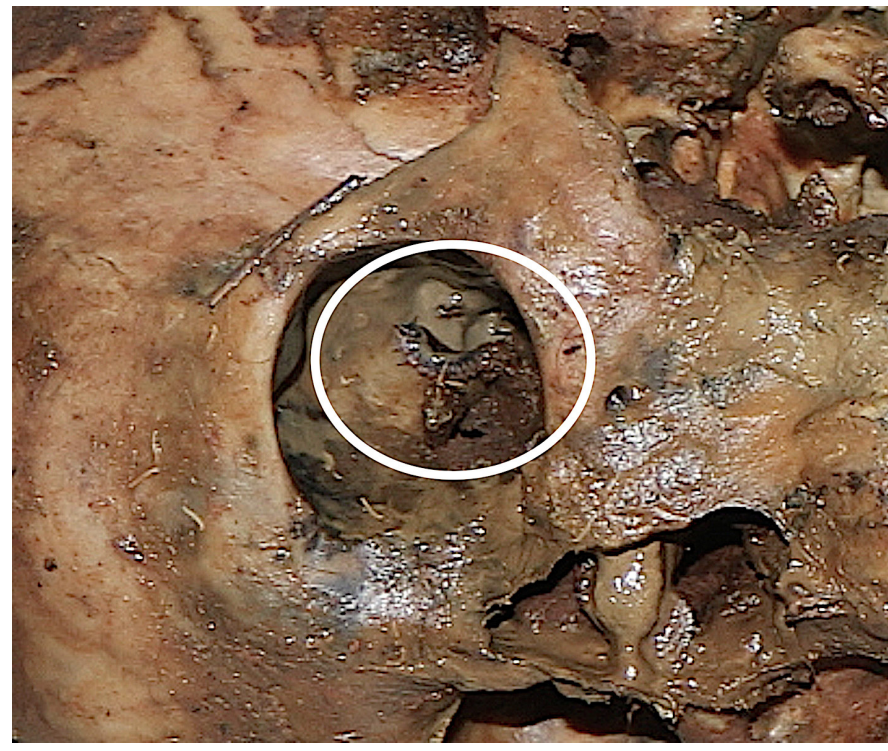

Figure 2. Oxelytrum discicolle larvae in the skull.

the University of Brasilia and kept under controlled conditions according to standard laboratory protocols in Forensic Entomology (Smith, 1986; Amendt et al., 2007), and later identified as O. discicolle (Fig. 1B).

The specimens of $O$. discicolle had a total length ranging from 14.9 to $18.2 \mathrm{~mm}$ and the maximum width of prothorax from 3.4 to $5.7 \mathrm{~mm}$, compatible with third instar larvae (Velásquez and Viloria, 2009; Velásquez and Viloria, 2010). We obtained the accumulation of degree-days (ADD) as follows: $A D D=y\left(T-T_{L}\right)$, where " $y$ " is the time required for developing in days; "T" is the temperature $\left({ }^{\circ} \mathrm{C}\right)$ of the environment in which larvae were collected (in this case, it was considered to be the average temperature of the area where the body was found, approximately $20^{\circ} \mathrm{C}$ at that time of the year, according to the nearest available weather database); and " $\mathrm{T}_{\mathrm{L}}$ " is the acceptable inferior threshold temperature $\left({ }^{\circ} \mathrm{C}\right)$ for the development of the species, which is $1.5^{\circ} \mathrm{C}$ (Velásquez and Viloria, 2009).

The results showed that the insects required 370 degree-days for their development to L3 stage in the conditions in which they were found, which is consistent with the available literature (Velásquez and Viloria, 2009; Velásquez and Viloria, 2010). The development stage of $O$. discicolle larvae, using the pre-appearance interval (PAI) (Matuszewski, 2011), allowed us to suggest that this species was part of an earlier colonization near the time of death, justified by the full length and prothorax width compatible with third instar larvae. The average time duration of each stage of development of this species at $20^{\circ} \mathrm{C}$, is as follows: egg (2.91 days); L1 (2 days); L2 (2 days); L3 (13.25 days); and pupae (9.5 days); therefore, the total time of insect development from egg to adult is 29.67 days at this temperature (Velásquez and Viloria, 2009). The data point that the colonization of the body by the carrion beetles, had originated from an earlier colonization in which the adult females must have oviposited over the corpse at least 20 days prior to the removal of the body from the place where it was found, characterizing the m-PMI (Fig. 3).

Over the past few years, beetles have been increasingly used as evidence in criminal investigations involving violent death, particularly with reference to dry human skeletal remains in the later stages of decomposition (Kulshrestha and Satpathy, 2001). This study puts carrion beetles (Silphidae) on par with skin beetles (Dermestidae) and bone beetles (Cleridae), which are regularly mentioned in the forensic literature, mainly in the Neotropical region, since it is the first time that a species of Silphidae has been used to estimate the PMI in the region. 


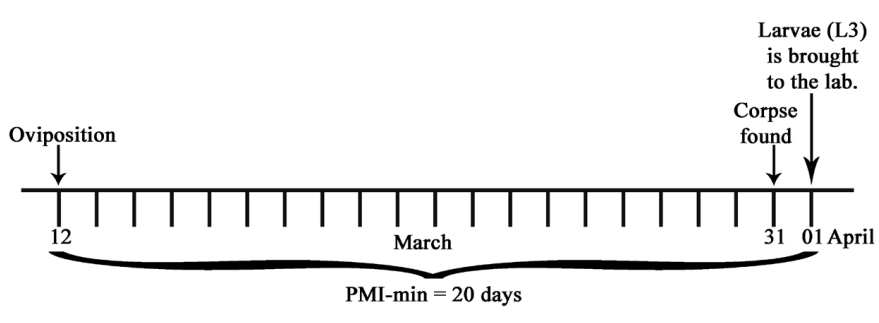

Figure 3. Timeline showing the entomological minimum PMI (post-mortem interval).

Previous research has suggested that when ephemeral resources at different stages of decomposition are available, $\boldsymbol{O}$. discicolle has a preference for the most decomposed substrate as a source of food, shelter, and oviposition (Lira et al., 2019), similar to the corpse in the present case. The larvae of $O$. discicolle are typically necrophagous and often found in the lower part of the carcasses, above the hardened soil layer that forms below decomposing corpses in the open air, once the active decomposition begins (Adriana Oliva, personal communication). Even though adults may appear early in the process of decomposition as predators and / or scavengers, first-instar larvae along with adults can occur as far as 10 to 15 days after death, and second and third instar larvae tend to appear by 20-25 days, usually without the presence of adults (Oliva, 2012).

The first time the genus Oxelytrum Gistel, 1848 was reported in a forensic case in Brazil was in 2014, when the beetles were found preying on Diptera larvae on a cadaver (Souza et al., 2014). Before that, in 2002, adults of $O$. discicolle were collected from several cadavers taken to a Forensic Medicine Institute in Colombia, but no larvae were reported, even though just adults of $O$. discicolle had been collected from these human corpses (Barreto et al., 2002). Our results strongly contrast with observations in decomposing carcasses in Southern Brazil where O.discicolle specimens were never found before 5 days after death in autumn and spring, or 30 days after death on winter days (Moura et al., 1997). The forensic importance of $O$. discicolle needed to be proven by their effective use as evidence in criminal investigations, in order to estimate the time of death.

As Matuszewski and Madra-Bielewicz (2019) have recently stated, the best species to estimate the PMI is the one that colonizes corpses earlier than all other insects sampled. For this case report, $O$. discicolle was efficient in colonizing the corpse near the date of death, similar to what has been observed for other species of the Silphidae family. Our records reinforce the effective use of the species to estimate the minimum post-mortem interval and support the role of beetles in cases of violent death with corpses found in advanced stages of decomposition.

\section{Acknowlegments}

We thank Prof. Dr. José Roberto Pujol-Luz (Universidade de Brasilia) for his invaluable support. We thank Msc. Kayla Scott (American School of Brasilia) and Dr. Diego Oliveira (Universidade Federal de Pernambuco) for their review of the English language. This research was funded by grants from Conselho Nacional de Desenvolvimento Científico e Tecnológico-CNPq, Fundação de Apoio à Pesquisa do Distrito Federal-FAP/DF, Financiadora de Estudos e Projetos-FINEP.

\section{Conflict of interest}

The authors declare no conflicts of interest.

\section{References}

Almeida, L. M., Corrêa, R. C., Grossi, P. C., 2015. Coleoptera species of forensic importance from Brazil: an updated list. Rev. Bras. Entomol. 59, 274-284.

Amendt, J., Campobasso, C. P., Gaudry, E., Reiter, C., LeBlanc, H. N., Hall, M. J. R., 2007. Best practice in forensic entomology-standards and guidelines. Int. J. Legal Med. 121, 90-104.

Barreto, M., Burbano, M. E., Barreto, P., 2002. Flies (Calliphoridae, Muscidae) and beetles (Silphidae) from human corpses in Cali, Colombia. Mem. Inst. Oswaldo Cruz 97, 137-138.

Carvalho, L. M., Thyssen, P. J., Linhares, A. X. F., Palhares, A. B., 2000. A checklist of arthropods associated with pig carrion and human corpses in Southeastern Brazil. Mem. Inst. Oswaldo Cruz 95, 135-138.

Kulshrestha, P., Satpathy, D. K., 2001. Use of beetles in forensic entomology. Forensic Sci. Int. 120, 15-17.

Lira, L. A., Macedo, M. P., Pujol-Luz, J. R., Vasconcelos, S. D., 2019. Diel activity and effect of carcass decomposition on the attractiveness to the forensically important species Oxelytrum discicolle(Coleoptera: silphidae). J. Forensic Sci. 64, 799-804.

Lira, L. A., Vasconcelos, S. D., 2016. New record and update on the distribution of Oxelytrum discicolle (Brulle, 1840) (Coleoptera: Silphidae) in South America. Coleopt. Bull. 70, 399-402.

Luederwaldt, G., 1911. Os insetos necrófagos paulistas. Rev. Mus. Paul. 08, 414-433.

Matuszewski, S., 2011. Estimating the pre-appearance interval from temperature in Necrodes littoralis L. (Coleoptera: silphidae). Forensic Sci. Int. 212, 180-188.

Matuszewski, S., Madra-Bielewicz, A., 2019. Post-mortem interval estimation based on insect evidence in a quasi-indoor habitat. Sci. Justice. 59, 109-115.

Mise, K. M., Almeida, L. M., Moura, M. O., 2007. Levantamento da fauna de Coleoptera que habita a carcaça de Sus scrofa L., em Curitiba, Paraná. Rev. Bras. Entomol. 51, 358-368.

Moura, O. M., Carvalho, C. J. B., Monteiro-Filho, E. L. A., 1997. A preliminary analysis of insects of medico-legal importance in Curitiba, State of Paraná. Mem. Inst. Oswaldo Cruz. 92, 269-274.

Oliva, A., 2012. A new species of Oxelytrum Gistel (Coleoptera: Silphidae) from southern Argentina, with a key to the species of the genus. ZooKeys. 203, 1-14.

Oliva, A., Di-Iorio, O. R., 2008. Silphidae In: Claps, L.E., Debandi, G., Roig-Junent, S. (Eds.), Biodiversidad de Artropodos Argentinos. vol. 2. Buenos Aires, Argentina: Sociedad Entomologica Argentina, pp. 461-70.

Peck, S. B., Anderson, R. S., 1985. Taxonomy, phylogeny and biogeography of the carrion beetles of Latin America (Coleoptera: silphidae). Quaest. Entomol. 21, 247-318.

Smith, K. G. V., 1986. A Manual of Forensic Entomology. Comstock Publishing Associates. Cornell Univ. Press, Ithaca, NY, pp. 205.

Souza, E. R., Rafael, J. A., Xavier Filho, F. F. X., Silva-Freitas, J. O., OliveiraCosta, J., Ururahy-Rodrigues, A., 2014. First medicolegal forensic entomology case of Central Amazon: A suicide by hanging with incomplete suspension. Entomobras. 7, 12-15.

Velásquez, Y., Viloria, A. L., 2009. Effects of temperature on the development of the Neotropical carrion beetle Oxelytrum discicolle(Brulle, 1840) (Coleoptera: silphidae). Forensic Sci. Int. 185, 107-116.

Velásquez, Y., Viloria, A. L., 2010. Instar determination of the Neotropical Oxelytrum discicolle (Coleoptera: silphidae). J. Med. Entomol. 47, 723-726. 